\title{
Positive Predictive Value of Serum Amylase in Predicting Acute Appendicitis taking Histopathology as Gold Standard
}

\author{
MUHAMMAD ASLAM JAVED ${ }^{1}$, SAJEEL AHMAD², VISHAL FARID RAZA ${ }^{3}$, KHALID JAVEED KHAN ${ }^{4}$ \\ ${ }^{1-4}$ Department of Surgery, Fatima Jinnah Medical University / Sir Ganga Ram Hospital Lahore. \\ Correspondence to: Dr. Muhammad Aslam Javed, Email: aslamjaved0304@gmail.com, Cell: 03045713206
}

\begin{abstract}
Background: Worldwide acute appendicitis is one of the most commonly encountered abdominal emergencies. Despite recent advances in imaging and laboratory parameters, the diagnosis still remains clinical. This study was carried out to determine positive predictive value of serum amylase in diagnosing acute appendicitis taking into account histopathology as gold standard.

Methods: Total 103 patients of both genders aged between 15-40 years presenting with pain and tenderness in right iliac fossa and vomiting having raised serum amylase $>85 \mathrm{U} / \mathrm{L}$ were included. These patients underwent appendectomy followed by histopathology of excised tissue. Diagnosis of appendicitis was confirmed on histopathology postoperatively and results of increased serum amylase levels were interpreted accordingly as true positive/ false positive. Informed consent was taken from all enrolled patients.

Results: Mean age of the enrolled patients was $27.8 \pm 7.5$ years. There were $59(57.3 \%)$ male and $44(42.7 \%)$ female patients, with a male to female ratio of 1.3:1. The BMl of enrolled patients ranged from $22.0 \mathrm{Kg} / \mathrm{m} 2$ to 34.4 $\mathrm{Kg} / \mathrm{m} 2$ with a mean of $26.9 \pm 3.4 \mathrm{Kg} / \mathrm{m} 2$. Diagnosis of appendicitis was confirmed in $93(90.3 \%)$ patients on histopathology. Thus there were 93 true positive and 10 false positive cases. It yielded a positive predictive value of $90.3 \%$ for serum amylase in predicting acute appendicitis taking histopathology as gold standard. Similar positive predictive value was noted across various subgroups based on age, gender and BMI.

Conclusion: In the present study, the positive predictive value of raised serum amylase was found to be $90.3 \%$ in predicting acute appendicitis which along with simplicity and routine availability of the test and low cost advocate the preferred use of this novel biomarker in the diagnostic workup of such patients in future surgical practice.

Keywords: Appendicitis, Serum Amylase, Positive Predictive Value
\end{abstract}

\section{INTRODUCTION}

Acute appendicitis has got the highest incidence in children and adolescents worldwide affecting every year around 5.7-57/per 100,000 individuals. 1 Variation of incidence is due to variations in age, sex, ethnicity, obesity and seasons of the year. Because of the belief that appendicitis is an irreversible rapidly progressive disease that can eventually lead to perforation and acute abdomen, the gold standard treatment of choice is surgical removal of appendix. The surgical field has gained much knowledge based on experiences in managing acute appendicitis patients ever since Fitz's first report in 1886.1

Despite being increased use of radiological investigations to reduce the frequency of negative appendicitis there are still studies which reports that it has not decreased significantly, and the postoperative morbidity of the negative appendicitis patient had been more than that of the actual acute appendicitis. 2

Salih et al.3 in 2017 conducted a study and found that the positive predictive value (PPV) of serum amylase in predicting acute appendicitis was $92.85 \%$.

The positive predictive value varies with the incidence of the disease and there is no local publish data present on this topic to the best of the candidate's knowledge. Also keeping in mind the fact that the radiological facilities haven't significantly reduced the frequency of negative appendectomy, and patients with negative appendectomy suffer from a significantly large number of complications than those with actual acute appendicitis. 2 There is a need to conduct this study in local population so that its PPV in local population could be detected and it will help us in reducing the frequency of negative appendectomy and the reduce the morbidity associated with it along with the economic burden on health services.

\section{METHODS}

It was a cross sectional study conducted at Department of Surgical Unit II, Sir Ganga Ram Hospital Lahore. The study was of 6 months duration starting from 10/12/2019 to 09/06/2020. After approval from ethical review committee of the hospital, 103 patients who presented in the Surgical Emergency, Sir Ganga Ram Hospital, Lahore and who were suspected to have acute appendicitis on serum amylase were enrolled into the study. Patients who had salivary gland enlargement or have undergone salivary gland surgery in past 4 weeks or patients who had pancreatitis in last 6 weeks as per clinical record and patients with bleeding disorder (INR > 1.5), liver impairment (serum bilirubin $>1.2 \mathrm{mg} / \mathrm{dl}$ ), cardiac murmur on auscultation or free fluid or appendicular mass on ultrasound as per clinical investigations were not included. $2 \mathrm{ml}$ blood was drawn and sent to the lab for serum amylase levels detection. After the consent for surgery and preparing the patient, the appendectomy was performed under aseptic condition as per protocol and the appendix was preserved in formalin and sent to lab for the histopathological examination. All the data was noted and recorded into the attached proforma along with demographic details of the patient. All the serum amylase levels were detected on the same machine of the hospital i.e. hospital machine and all the histopathological examinations were done by the same consultant of the histopathology department to eliminate bias and confounding variables were controlled by exclusion. 


\section{RESULTS}

The enrolled patient age ranged from $15-40$ years with a mean age of $27.8 \pm 7.5$ years.

There were 59 (57.3\%) male patients and 44 (42.7\%) female in the study group with a male to female ratio of 1.3:1. The BMl of enrolled patients ranged from $22.0 \mathrm{~kg} / \mathrm{m}^{2}$ to $34.4 \mathrm{~kg} / \mathrm{m}^{2}$ with a mean of $26.9 \pm 3.4 \mathrm{~kg} / \mathrm{m}^{2}$ as shown in Table1.

Table 1: Baseline Characteristics $(n=103)$

\begin{tabular}{|l|l|}
\hline Characteristics & $\begin{array}{l}\text { Participants } \\
n=103\end{array}$ \\
\hline Age & $27.8 \pm 7.5$ \\
\hline $15-27$ years & $53(51.5 \%)$ \\
\hline $28-40$ years & $50(48.5 \%)$ \\
\hline Gender & $59(57.3 \%)$ \\
\hline Male & $44(42.7 \%)$ \\
\hline Female & $41(39.8 \%)$ \\
\hline BMl $\left(\mathrm{Kg} / \mathrm{m}^{2}\right)$ & $42(40.8 \%)$ \\
\hline $20-25 \mathrm{Kg} / \mathrm{m}^{2}$ & $20(19.4 \%)$ \\
\hline $25-30 \mathrm{Kg} / \mathrm{m}^{2}$ &
\end{tabular}

Diagnosis of appendicitis was confirmed in 93 (90.3\%) patients on histopathology. Thus there were 93 true positive and 10 false positive cases. It yielded a positive predictive value of $90.3 \%$ for serum amylase in predicting acute appendicitis taking histopathology as gold standard as shown in Table 2.

Table 2: Frequency of Appendicitis on Histopathology and Positive Predictive Value of Raised Serum Amylase $n=103$

\begin{tabular}{|l|l|l|}
\hline Appendicitis on H/P & Frequency (n) & Percent (\%) \\
\hline Yes (True Positive) & 93 & 90.3 \\
\hline No (False Positive) & 10 & 9.7 \\
\hline Total & 103 & 100.0 \\
\hline
\end{tabular}

Table 3: Stratification of Positive Predictive Value across Age Groups n=103

\begin{tabular}{|c|c|c|c|c|c|}
\hline \multirow[t]{2}{*}{ Age Groups } & \multicolumn{2}{|c|}{ Diagnosis on $\mathrm{H} / \mathrm{P}$} & \multirow[t]{2}{*}{ Total } & \multirow[t]{2}{*}{ PPV } & \multirow[t]{2}{*}{ P-value } \\
\hline & \begin{tabular}{|l} 
True \\
Positive \\
$(n=93)$
\end{tabular} & $\begin{array}{l}\text { False } \\
\text { Positive } \\
(n=10)\end{array}$ & & & \\
\hline \multirow{2}{*}{$\begin{array}{l}15-27 \text { years } \\
(\mathrm{n}=53)\end{array}$} & 48 & 5 & 53 & \multirow[t]{2}{*}{$90.6 \%$} & \multirow{4}{*}{0.923} \\
\hline & $90.6 \%$ & $9.4 \%$ & $100.0 \%$ & & \\
\hline \multirow{2}{*}{$\begin{array}{l}28-40 \text { years } \\
(n=50)\end{array}$} & 45 & 5 & 50 & \multirow{2}{*}{$90.0 \%$} & \\
\hline & $90.0 \%$ & $10.0 \%$ & $100.0 \%$ & & \\
\hline \multirow[t]{2}{*}{ Total } & 93 & 10 & 103 & & \\
\hline & $90.3 \%$ & $9.7 \%$ & $100.0 \%$ & & \\
\hline
\end{tabular}

Chi-square test, observed difference was statistically insignificant, PPV: positive predictive value

Table 4: Stratification of Positive Predictive Value across Gender $\mathrm{n}=103$

\begin{tabular}{|c|c|c|c|c|c|}
\hline \multirow[t]{2}{*}{ Gender } & \multicolumn{2}{|c|}{ Diagnosis on $\mathrm{H} / \mathrm{P}$} & \multirow[t]{2}{*}{ Total } & \multirow[t]{2}{*}{ PPV } & \multirow[t]{2}{*}{ P-value } \\
\hline & \begin{tabular}{|l} 
True \\
Positive \\
$(\mathrm{n}=93)$
\end{tabular} & \begin{tabular}{|l} 
False \\
Positive \\
$(\mathrm{n}=10)$
\end{tabular} & & & \\
\hline \multirow[t]{2}{*}{ Male $(n=59)$} & 53 & 6 & 59 & \multirow[b]{2}{*}{$89.8 \%$} & \multirow[b]{4}{*}{0.855} \\
\hline & $89.8 \%$ & $10.2 \%$ & $100.0 \%$ & & \\
\hline \multirow[t]{2}{*}{ Female $(n=44)$} & 40 & 4 & 44 & \multirow[b]{2}{*}{$90.9 \%$} & \\
\hline & $90.9 \%$ & $9.1 \%$ & $100.0 \%$ & & \\
\hline \multirow[t]{2}{*}{ Total } & 93 & 10 & 103 & & \\
\hline & $90.3 \%$ & $9.7 \%$ & $100.0 \%$ & & \\
\hline
\end{tabular}

Chi-square test, observed difference was insignificant, PPV (positive predictive value)
Similar positive predictive value was noted across various subgroups based on age, gender and BMI as shown in Tables $3-5$ respectively.

Table 5: Stratification of Positive Predictive Value across BMI $n=103$

\begin{tabular}{|l|l|l|l|l|l|}
\hline BMI & $\begin{array}{l}\text { Diagnosis } \\
\text { on H/P }\end{array}$ & Total & PPV & P-value & \\
\hline & $\begin{array}{l}\text { True } \\
\text { Positive } \\
(\mathrm{n}=93)\end{array}$ & $\begin{array}{l}\text { False } \\
\text { Positive } \\
(\mathrm{n}=10)\end{array}$ & & & \\
\hline $\begin{array}{l}20-25 \mathrm{Kg} / \mathrm{m} 2 \\
(\mathrm{n}=41)\end{array}$ & 37 & 4 & 41 & $90.2 \%$ & 0.998 \\
\hline & $90.2 \%$ & $9.8 \%$ & $100.0 \%$ & & \\
\hline $\begin{array}{l}25-30 \mathrm{Kg} / \mathrm{m} 2 \\
(\mathrm{n}=42)\end{array}$ & 38 & 4 & 42 & $90.5 \%$ & \\
\hline & $90.5 \%$ & $9.5 \%$ & $100.0 \%$ & & \\
\hline $\begin{array}{l}30-35 \mathrm{Kg} / \mathrm{m}^{2} \\
(\mathrm{n}=20)\end{array}$ & 18 & 2 & 20 & $90.0 \%$ & \\
\hline & $90.0 \%$ & $10.0 \%$ & $100.0 \%$ & & \\
\hline Total & 93 & 10 & 103 & & \\
\hline & $90.3 \%$ & $9.7 \%$ & $100.0 \%$ & & \\
\hline
\end{tabular}

Chi-square test, observed difference was insignificant, PPV (positive predictive value)

\section{DISCUSSION}

The diagnosis of acute appendicitis is usually based on clinical signs and symptoms and can be exigent even in the most experienced clinical hands. An accurate diagnosis is very important in order to avoid unnecessary surgery and complications. The diagnosis is usually made with the patient's medical history, general physical and systemic examination, and laboratory investigations; however, its preoperative diagnosis is increasingly dependent on radiological imaging. ${ }^{1}$

The Alvarado scoring system was originally outlined in 1986 and it is the most widely accepted scoring system for acute appendicitis. This scoring system alone is not accurate and reliable enough to confirm clinical diagnosis or to exclude appendicitis. ${ }^{4}$ Till today there is no specific diagnostic test available for acute appendicitis diagnosis, but the prudent use of simple urine and blood tests, particularly inflammatory response markers, should allow exclusion of other diseases that have similar clinical presentation. ${ }^{5}$ Other algorithms and scoring systems have been widely proposed to support establishing the diagnosis of acute appendicitis but have not been widely accepted. ${ }^{1}$ Therefore there is need for non-invasive predictor of appendicitis which should be more reliable yet cheap and widely available. A recent study reported that raised serum amylase carried high positive predictive value in establishing the diagnosis of acute appendicitis which along with low cost and wide spread availability favored its routine use. ${ }^{3}$ However, the existing evidence was limited. Moreover, there was no such locally published data which entailed the need for present study.

The objective of this study was to determine the positive predictive value of serum amylase in predicting acute appendicitis taking histopathology as gold standard.

In our study, the mean age of enrolled patients with acute appendicitis ranged from $27.8 \pm 7.5$ year. A similar mean age among patients of acute appendicitis was previously reported by Al-Shahwany et al. ${ }^{6}$ in $2012(27 \pm 12$ years) in Iraq and Rather et al. ${ }^{7}$ in 2013 (26 \pm 11 years) in India. 
Kanumba et al. ${ }^{8}$ in 2011 observed a comparable mean age of $29.6 \pm 12.9$ years among such patients in Africa. Tsai et al. ${ }^{9}$ in 2015 reported much higher mean age of 33.0 \pm 22.0 years in acute appendicitis patients in Taiwan. A relatively younger mean age of $24.8 \pm 9$ years was witnessed by Memon et al. ${ }^{10}$ in 2009 in patients presenting at Pakistan Institute of Medical Sciences Islamabad with acute appendicitis. Jalil et al. ${ }^{11}$ in 2011 (22.3 \pm 7.7 years) and Soomro et al. ${ }^{12}$ in 2008 (20.5 years) however reported much younger mean age in local population.

We observed that there were 59 (57.3\%) male patients and $44(42.7 \%)$ female acute appendicitis patients with a male to female ratio of 1.3:1. A study conducted by Jalil et $\mathrm{a}^{11}$. in 2011, a similar male predominance among such patients has also been observed that is (1.4:1), Soomro et al. ${ }^{12}$ in 2008 (1.9:1), Memon et al. ${ }^{10}$ in 2009 (1.9:1). Talukder et al. ${ }^{13}(1.3: 1)$ in Bangladeshi population, Beek et al. ${ }^{14}$ in 2015 (1.2:1), Netherlands and Pogorelić et al. ${ }^{15}$ in 2015 (1.2:1) in European population also reported a similar male predominance among such patients. Kanumba et al. ${ }^{8}$ however observed female predominance $(1: 2.4)$ in African patients of acute appendicitis.

We observed that raised serum amylase $>85 \mathrm{U} / \mathrm{L}$ carried a PPV of $90.3 \%$ in the diagnosis of appendicitis regardless of patient's gender, age and BMI. Our observation is in line with the previously published reported by Salih et al. ${ }^{3}$ in 2017 who observed the positive predictive value of serum amylase to be $92.9 \%$ in predicting acute appendicitis in Iraqi population. A relatively higher PPV of $100.0 \%$ has been reported by Amanollahi et al. ${ }^{16}$ (2018) in Iran.

Our study is first of its kind in our local population and adds to the limited already published research trials on the topic. In our study, the positive predictive value of raised serum amylase was found to be $90.3 \%$ in predicting acute appendicitis which along with simplicity and routine availability of the test and low cost advocate the preferred use of this novel biomarker in the diagnostic workup of such patients in future surgical practice. A very important point regarding serum amylase is that it has been traditionally used as a marker of acute pancreatitis. ${ }^{3}$ As both the acute appendicitis and pancreatitis present with pain abdomen and vomiting, therefore one must keep in mind that a raised serum amylase level should also alert the surgeon about the probability of appendicitis in addition to pancreatitis. Further help can be taken from careful clinical evaluation of patient from history and examination followed by necessary imaging workup to reach a diagnosis. Earlier diagnosis of acute pancreatitis and appendicitis is vital to prevent complications and improve the outcome.

A significant limitation to our study was that we haven't considered the response of antibiotic treatment on serum amylase levels and its relation to the final patient outcome in terms of successful conservative management or need for surgical intervention which could have further shed light on the role of serum amylase in the risk stratification and management planning of such cases. Such a study is highly recommended in future research.

\section{CONCLUSION}

In our study, the positive predictive value of raised serum amylase was found to be $90.3 \%$ in predicting acute appendicitis which along with simplicity and routine availability of the test and low cost advocate the preferred use of this novel biomarker in the diagnostic workup of such patients in future surgical practice.

\section{REFERENCES}

1. Ceresoli M, Zucchi A, Allievi N, Harbi A, Pisano M, Montori $\mathrm{G}$, et al. Acute appendicitis: Epidemiology, treatment and outcomes-analysis of 16544 consecutive cases. World $\mathrm{J}$ Gastrointest Surg 2016;8(10):693-9.

2. Jeon BG. Predictive factors and outcomes of negative appendectomy. Am J Surg 2017;213(4):731-8.

3. Salih IK, AI-Dabbagh AJ, Hassan QA. The value of inflammatory markers in acute appendicitis: a diagnostic accuracy study. Pak J Med Health Sci 2017;11(4):1607-11.

4. Gorier RR, Eker HH, Gorter-Stam MAW, Abis GSA, Acharya A, Ankersmit M, et al. Diagnosis and management of acute appendicitis. EAES consensus development conference 2015. Surg Endosc 2016;30(11):4668-90.

5. Gomes CA, Sartelli M, Di Saverio S, Ansaloni L, Catena F, Coccolini, F, et al. Acute appendicitis: proposal of a new comprehensive grading system based on clinical, imaging and laparoscopic findings. World $J$ Emerg Surg 2015;10(7):60-9.

6. Al-Shahwany IW, Hindoosh LN, Rassam R, AI-Qadhi A. Drain or Not to Drain in Appendectomy for Perforated Appendicitis. J Iraq Postgrad Med 2012;11(3):349-52.

7. Rather SA, Bari SUL, Malik AA, Khan A. Drainage vs. no drainage in secondary peritonitis with sepsis following complicated appendicitis in adults in the modern era of antibiotics. World J Gastrointest Surg 2013;5(11):300-5.

8. Kanumba ES, Mabula JB, Rambau P, Chalya PL. Modified Alvarado Scoring System as a diagnostic tool for acute appendicitis at Bugando Medical Centre, Mwanza, Tanzania. BMC Surg 2011;11(3):4-11.

9. Tsai MS, Lai PS, Hung JS, Lee CY, Lee PC, Lai HS, et al. The efficacy and safety of intra- abdominal drainage after emergency laparoscopic appendectomy for complicated appendicitis. E- Da Med J 2015;2:8-14.

10. Memon AH, Vohra LM, Khaliq T, Lehri AA. Diagnostic accuracy of Alvarado score in the diagnosis of acute appendicitis. Pak J Med Sci 2009;25(1):118-21.

11. Jalil A, Shah SA, Saaiq M, Zubair M, Riaz U, Habib Y. Alvarado scoring system in prediction of acute appendicitis. J Col Physicians Surg Pak 2011;21(12):753-5.

12. Soomro AG, Siddiqui FG, Abro AH, Abro S, Shaikh NA, Memon AS. Diagnostic accuracy of Alvarado scoring system in acute appendicitis. J Liaquat Univ Med Health Sci 2008;4:93-6.

13. Talukder DB, Siddiq AKMZ. Modified Alvarado scoring system in the diagnosis of acute appendicitis. JAFMC Bangladesh 2009;5(1):18-20.

14. Beek MA, Jansen TS, Raats JW, Twiss EL, Gobardhan PD, Kloot EJ. The utility of peritoneal drains in patients with perforated appendicitis. Springer Plus 2015;4:371.

15. Pogorelić Z, Rak S, Mrklić I, Jurić I. Prospective validation of Alvarado score and Pediatric Appendicitis Score for the diagnosis of acute appendicitis in children. Pediatr Emerg Care 2015;31(3):164-8.

16. Amanollahi $\mathrm{O}$, Tat $\mathrm{S}$. The study of diagnostic value of elevation of serum amylase as a predictive factor for appendiceal perforation in children with acute appendicitis. Int J Pediatr 2018;6(2):7213-7. 